\title{
Adaptive genetic potential of European silver fir in Romania in the context of climate change
}

\author{
G. Mihai, M.-V. Bârsan, A. Dumitrescu, A. Alexandru, I. Mirancea, P. Ivanov, \\ E. Stuparu, M. Teodosiu, M. Daia
}

Mihai G., Bârsan M.-V., Dumitrescu A., Alexandru A., Mirancea I., Ivanov P., Stuparu E., Teodosiu M., Daia M., 2018. Adaptive genetic potential of European silver fir in Romania in the context of climate change. Ann. For. Res. 61(1): 95-108.

Abstract. Five provenance tests with twenty-six European silver fir autochthonous populations were used in order to assess the response of populations to climate change. Height growth and diameter at breast height of trees at age 31 years were considered as response variables and eight climate variables as predictors. Climatic variables for the trial sites and for origin location of provenances were calculated from 1961 to 2010. The experiments revealed a large genetic variability within species level and a plastic response to climate change, which certainly has a genetic basis. The transfer to warmer climate has resulted in an increase of the provenances growth, in the trial sites situated on the lower vegetation layer. But growth is significantly influenced by mean annual temperature and annual precipitation of planting site and also by the differences in mean annual temperature, annual precipitation, monthly mean temperature in July and July precipitation between provenance site and test site. These are the climatic factors which should be associated with risk in case of the transfer of forest reproductive materials. The provenance origin should be especially considered if the species will be planted outside of its current climate optimum. The best provenances in terms of total height and diameter at $1.30 \mathrm{~m}$ came from origin climate close to site climate, small transfer distances. Based on growth response functions and RCP4.5 scenario, we could project the shifts in species distribution for 2050 s and 2100 s and identify vulnerable populations.

Keywords Silver fir, transfer functions, response functions, local adaptation, phenotypic plasticity, climate changes impact

Authors. Georgeta Mihai (gmihai2008@yahoo.com), Alin Alexandru, Ionel Mirancea, Paula Ivanov, Elena Stuparu, Maria Teodosiu - "Marin Drăcea" National Institute for Research and Development in Forestry, Department of Forest Genetics and Tree Breeding, Bucharest, Romania; Marius-Victor Bîrsan, Alexandru Dumitrescu - National Meteorological Administration (Meteo Romania), Department of Climatology, Bucharest, Romania; Mihai Daia - National Forest Administration (RNP-Romsilva), Department of Forest Regeneration, Bucharest, Romania.

Manuscript received January 31, 2018; revised May 29, 2018; accepted June 14, 2018; online first July 12, 2018. 


\section{Introduction}

Researchers in the last decades have revealed a clear change in global climate, which cannot remain without effects on forest ecosystems. The most pessimistic climate change scenarios indicate increase of $4^{\circ} \mathrm{C}$ and higher in average annual air temperature until the end of the century, as well as changes in the rainfall regime and in the frequency of some extreme events (Salinger 2005). In Romania, the annual air temperature is projected to increase by $1.2^{\circ} \mathrm{C}$ during 2021-2050 compared to 1991-2020 (Cheval et al. 2017), and by over $2{ }^{\circ} \mathrm{C}$ in 100 years, i.e., 1961-1990 vs. 2061-2090 (Bojariu et al. 2015).

There is a high degree of uncertainty regarding climatic influences on forest growth, health and stability. It is still widely accepted that phenology and species composition will be substantially modified, and the productivity and stability of forest ecosystems will be reduced. Forest species adapt on the long term by natural selection, migration to other habitats or phenotypic plasticity (Price et al. 2003). The real potential for adaptation depends upon the existence of a wide genetic diversity in tree population, upon the adaptive genetic variation, respectively. Genetic diversity, as the first level of biodiversity, offers the guarantee that forest species can survive, can adapt and evolve under the influence of changing environmental conditions.

Therefore, assessment of adaptive genetic potential of local species is essential for increasing forest productivity and stability in the context of climate changes. Proper choice of tree species and provenances with high plasticity are decisive for increasing the adaptability of tree populations to rapid environmental changes. The report of the European Forest Institute (EFI 2008) calls the regeneration strategy, including artificial regeneration, and forest tree breeding as one of the most important measures in a strategy to adapt forests to climate change. In addition, scientific evidence reveals that natural adaptation mechanisms of forest trees to buffer effects of climate change may not be sufficient to keep forests' ecosystem and economic functions intact (Savolainen et al. 2004, Jump et al. 2006, Aitken et al. 2008). The transfer of forest reproductive material adapted to environmental changes or the "assisted migration" is considered one of the measures that can facilitate adaptation of forest species and maximize forest productivity (Kremer 2007, Lindner 2000).

European silver fir is one of the most important forest tree species comprising 4\% from national forest area in Romania and 7\% from total regenerated area (NSI 2015). European silver fir is an extremely demanding species to site conditions (Şofletea \& Curtu 2001), and also less tolerant to environmental changes than other species, like European larch, white pine (Weisgerber \& Sindelar 1992, Rehfeldt 1994a, Ficko et al. 2011). It is a main component of mountainous forests in Romania and has manifold ecological, economical and soil protective functions. Both anthropic and environment pressures on European silver fir populations increased in the last decades and focus on adaptive traits has become a new priority.

In order to predict the impact of future climate change on tree phenotypes, the environmental and genetic effects need to be considered and quantified. It is generally hypothesized that tree populations are best adapted to their local climate conditions. Therefore, the best growth performance is expected at small climate transfer distances, whereas at larger climatic distances, trees are expected to perform poorly due to lack of adaptation (Kapeller et al. 2012).

To obtain climate-related responses different approaches can be used. In this study, we used two primary approaches: population transfer functions and population response functions. Both have been used to predict the response of forest trees populations to climate change, and to make recommendations about provenance selection as seed sources, breeding population establishment, and reforestation for uncertain 
future climates (Schmidtling 1994, Aitken et al. 2008, Farjat et al. 2015).

The objectives of this study were: (1) to examine the genetic variability and patterns of adaptation of European silver fir populations, (2) to develop models to predict the adaptability of populations to climate changes, (3) to determine the potential impact of the climate change on tree growth, (4) to provide practical information for the use and transfer of forest reproductive material in Romania.

\section{Materials and methods}

\section{Genetic material and experimental design}

In 1980, seven field trials were established with 6-year old seedlings from 26 European silver fir autochthonous populations. Two of the field trials exhibited poor survival and could not be continued beyond age 20 years. Therefore, only five trials were considered in this study. The trials were established in different geographic regions, two of them (Bautar and Domnesti) being located outside of the natural range of species in Romanian Carpathians, in the mountain beech layer, in climatically warmer sites and three within the natural range, in the mixed mountain layer. The

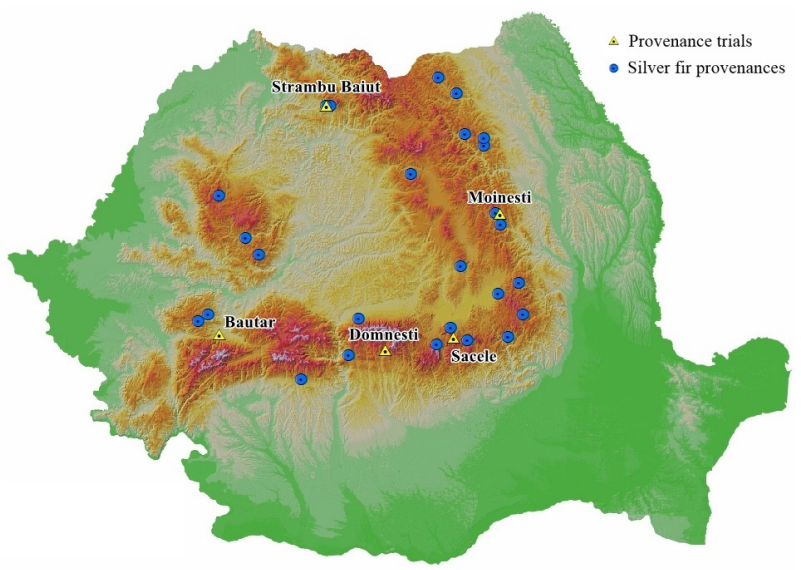

Figure 1 Location of European silver fir provenances and the comparative trials tested populations are from seven geographic regions and nine sub-regions respectively, which were defined as provenance regions for European silver fir in Romania (Parnuta et al. 2012). Locations of the field trials and of the provenances are presented in Figure 1. In all sites the field layout was a randomised square lattice with 4 replications and 25 -tree per plots at $1.0 \mathrm{~m} \times 2.0 \mathrm{~m}$ spacing.

\section{Data analysis}

For analyses we consider the height growth (H31) and diameter at breast height (D31) of trees at age 31 years as response variables. Height and diameter growth can be considered adaptive traits because they are under natural selection more than other traits and also have high heritability (Mihai et al. 2014, Mihai \& Mirancea 2016).

Climatic conditions for the trial sites and the origin location of provenances were represented by four temperature variables: the annual mean temperature (TMA), the mean temperature of the coldest month $\left(\mathrm{TM}_{\mathrm{JAN}}\right)$, the mean temperature of the warmest month $\left(\mathrm{TM}_{\mathrm{JUL}}\right)$, the annual mean temperature during vegetation season $\left(\mathrm{TM}_{\mathrm{VEG}}\right)$, and four precipitation variables: the annual mean total precipitations (PMA), the mean precipitation of the coldest month $\left(\mathrm{PM}_{\mathrm{JAN}}\right)$, the mean precipitation of the warmest month $\left(\mathrm{PM}_{\mathrm{JUL}}\right)$ and the annual mean total precipitation during growing season (PM$\left.{ }_{\mathrm{VEG}}\right)$. Also, the De Martonne index was calculated for each trial site (Marcu 1983).

For all analyses we used as basic data the monthly values of the climatic parameters. Climatic variables of the five trial sites were obtained by averaging the monthly observations for the period 19812010. Climatic variables of the location of provenances were calculated over a twenty year period, 
from 1961 to 1980 . The climatic variables were estimated using an improved version of the ROCADA daily gridded dataset (Dumitrescu \& Birsan 2015), a state-of-the-art homogenized climatic dataset over Romania at a spatial resolution of $0.1^{\circ} \times 0.1^{\circ}$. In order to better assess the spatial variability of the parameters, this dataset has been spatially downscaled by spatial interpolation techniques (Dumitrescu et al. 2016, 2017) to a resolution of $1 \mathrm{~km} \mathrm{x} 1 \mathrm{~km}$. Future (projected) climatic data were derived from the Regional Climate Model (RCM) CLMcom-CCLM4-8-17 forced by the Global Circulation Model (GCM) MPI-M-MPI-ESMLR run1 (http://mpimet.mpg.de/en/science/ models/mpi-esm/), following the RCP (Representative Concentration Pathway) 4.5 Scenario (Thomson et al. 2011), at a spatial resolution of $0.11^{\circ} \times 0.11^{\circ}$. RCP 4.5 is a scenario that presents a moderate change in temperature and precipitation, stabilizing radiative forcing at $4.5 \mathrm{~W} / \mathrm{m}^{2}$ in 2100 without ever exceeding that value. The projected climate periods analyzed in this article are 2021-2050 and 2071-2100.

\section{Statistical analysis}

Analyses of variance were performed for each trial site and among sites using GLM procedure (SPSS programme version 19). The total amount of variation was divided into provenances, provenance regions, sites components, and interaction between them. All effects were considered as random except for the trials location, which was considered as fixed. Data for H31 and D31 were examined and found to conform to the normal distribution and homogeneity of variance assumption.

The ANOVA were performed as described in the following mixed model:

$$
Y_{i j k l n}=\mu+R_{k}+S_{l}+B_{i}+P_{j}+S P_{l j}+B P_{i j}+e_{i j k k n}
$$

where: $Y_{i j k l n}=$ response (H31 or D31), $\mu=$ the overall mean, $R_{k}, S_{l}, B_{i}, P_{j}, S P_{l j}, B P_{j i}$ and $e_{i j k l n}$ are effect due to $k^{\text {th }}$ region, $l^{\text {th }}$ site, $i^{\text {th }}$ repetition (block), $j^{\text {th }}$ provenance, interaction due to 98 $l^{\text {th }}$ site and $j^{\text {th }}$ provenance, interaction due to $i^{\text {th }}$ repetition and $j^{\text {th }}$ provenance, and random error associated with ijkln ${ }^{\text {th }}$ trees.

Phenotypic plasticity of the provenances for each trait was evaluated by calculating the ecovalence and its variance. Ecovalence represents the contribution of each provenance to the total provenance $\mathrm{x}$ site interaction sum of squares. For this reason, provenances with low ecovalence values have smaller deviation from the mean across environments and are thus more stable. Ecovalences were computed by the following formulas (Wrike 1962):

$$
W_{i}=\Sigma_{j}\left(X_{i j}-X_{i}-X_{\bullet_{j}}+X_{. .}\right)^{2}
$$

where: $W_{i}$ - ecovalence of provenance i, $X_{i j}$ mean of provenance $\mathrm{i}$ in environment $\mathrm{j}, X_{i}$. mean of provenance $i$ across environments, $X{ }_{j}$ - environment mean, $X$.. - overall mean.

Populations transfer functions were then developed using H31 and D31 as dependent variables and difference between the climate of each provenance location and of the trial site as predictors (Matyas 1994, Rehfeldt et al. 1999b, Andalo et al. 2005). Transfer functions are test site specific (Wang et al. 2010) and therefore we calculated them for each trial site. Because the relationship between growth and climate did not follow linearity (Rehfeldt et al. 1999a) we modeled the response to transfer using quadratic regressions. Three types of climate transfer models were constructed: (1) based on temperature, (2) based on precipitation and (3) both temperature and precipitation (Table 1). Since there were four temperature variables and four precipitation variables, a total of 136 models were developed. For variables selection, we used the stepwise selection method of SPSS software. The best models were selected based on $R^{2}$ coefficients.

In order to account the environmental effects of trial sites on the performances of tested provenances, the growth response functions were also developed. For modelling populations response functions the quadratic regressions were considered appropriate. Thus, the 
Table 1 Types of quadratic models used

\begin{tabular}{lll}
\hline Transfer model & D_Tij variable & D_Pij variable \\
\hline$Y_{i j}=\beta_{0}+\beta_{1} D_{-} T i j+\beta_{2}\left(D_{-} T i j\right)^{2}$ & & \\
$Y_{i j}=\beta_{0}+\beta_{1} D_{-} P i j+\beta_{2}\left(D_{-} P i j\right)^{2}$ & & \\
$Y_{i j}=\beta_{0}+\beta_{1}\left(D_{-} T i j\right)^{2}+\beta_{2}\left(D_{-} P i j\right)^{2}$ & & \\
$Y_{i j}=\beta_{0}+\beta_{1} D_{-} T i j+\beta_{2}\left(D_{-} P i j\right)^{2}$ & & \\
$Y_{i j}=\beta_{0}+\beta_{1}\left(D_{-} T i j\right)^{2}+\beta_{2} D \_P i j$ & $D_{-} T M A / D_{-} T M_{J A N} /$ & $D_{-} P M A / D_{-} P M_{J A N} /$ \\
$Y_{i j}=\beta_{0}+\beta_{1} D_{-} T i j+\beta_{2}\left(D_{-} T i j\right)^{2}+\beta_{3} D_{-} P i j$ & $D_{-} T M_{J U L} / D_{-} T M_{V E G}$ & $D_{-} P M_{J U L} / D_{-} P M_{V E G}$ \\
$Y_{i j}=\beta_{0}+\beta_{1} D_{-} T i j+\beta_{2}\left(D_{-} T i j\right)^{2}+\beta_{3}\left(D_{-} P i j\right)^{2}$ & & \\
$Y_{i j}=\beta_{0}+\beta_{1} D_{-} T i j+\beta_{2} D_{-} P i j+\beta_{3}\left(D_{-} P i j\right)^{2}$ & & \\
$Y_{i j}=\beta_{0}+\beta_{1} D_{-} P i j+\beta_{2}\left(D_{-} T i j\right)^{2}+\beta_{3}\left(D_{-} P i j\right)^{2}$ & \\
$Y_{i j}=\beta_{0}+\beta_{1} D_{-} T i j+\beta_{2} D_{-} P i j+\beta_{3}\left(D_{-} T i j\right)^{2}+\beta_{4}\left(D_{-} P i j\right)^{2}$ & & \\
\hline
\end{tabular}

Note. Abbreviations: Yij - the mean H31 or D31 of the provenance i at site j, D Tij - the difference between the temperature conditions at the location of provenance $\mathrm{i}$ and at the trial site $\mathrm{j}, D_{-} P i j$ - the difference between the precipitation at the location of provenance $i$ and at the trial site $\mathrm{j}$.

populations' means for H31 and D31 were regressed on climate variables of the plantation sites.

To simulate potential impact of climate change on European silver fir populations, we used the obtained growth response function to model the future European silver fir distribution for the climate change scenario RCP4.5 for means of two time periods, namely 20212050 and 2071-2100.

\section{Results}

\section{Genotype $x$ environment interaction}

Significant differences among provenances were found for growth traits at each trial site and across-sites. The analysis of variance across sites is presented in Table 2. The genetic variation among provenances was significant and represented $2-3 \%$ of total variance. The differences among regions of provenances were also significant both for H31 and D31.

The influence of site factor was greater than genetic factor and accounted for $78 \%$ (for $\mathrm{H} 31$ ) and $45 \%$ (for D31) of the total variance. These differences can be associated with climatic characteristics of the trial sites relating to temperature and precipitation or with other ecological factors not considered in this arti- cle. Thus, TMA and PMA have varied substantially among trial sites with $2.3^{\circ} \mathrm{C}$ temperature and $234 \mathrm{~mm}$ precipitation differences, respectively (Table 3 ). Also, the provenance $\mathrm{x}$ site interaction was significant, indicating that growth performances of provenances depend on environment of planting site and they could change with changing the site conditions. The highest growth performances occurred at Domnești and Băuțar trials situated in the mountain beech layer. Depending of values of De Martonne aridity index (Marcu 1983) the trial sites could be divided into two categories: wet (Moinești, Domnești and Băuțar trials) and very wet (Săcele and Strâmbu Băiuț trials).

\section{Populations transfer functions}

For modelling populations' response to climatic transfer among geographic regions we used growth traits as the response variables and climatic distances (difference in climate value between the origin location of a given provenance and the test site) as independent variables.

The transfer functions were calculated for each growth trait in each trial site. The best models were selected based on higher proportion of variance explained $\left(R^{2}\right)$ and were presented in Table 4 and 5. Thus, the best models have included both temperature and precipita- 
Table 2 Analysis of variance and genotype x environment interaction of growth traits at 31 years old

\begin{tabular}{|c|c|c|c|c|c|c|}
\hline \multirow[b]{2}{*}{ Source of variation } & \multicolumn{3}{|l|}{$\mathrm{H} 31$} & \multicolumn{2}{|l|}{ D31 } & \multirow[b]{2}{*}{$\begin{array}{l}\% \text { from } \\
\text { total } \\
\text { variation }\end{array}$} \\
\hline & DF & $s^{2}$ & $\begin{array}{l}\% \text { from } \\
\text { total } \\
\text { variation }\end{array}$ & DF & $s^{2}$ & \\
\hline Region of provenance (R) & 9 & $2.856^{*}$ & 1 & 9 & $6.412 *$ & 2 \\
\hline Provenance $(\mathrm{P})$ & 26 & $2.368^{*}$ & 2 & 26 & $4.209 *$ & 3 \\
\hline Site $(\mathrm{S})$ & 4 & $657.790 * * *$ & 78 & 4 & $359.901 * * *$ & 45 \\
\hline Repetition & 3 & 21.169 & 2 & 3 & 27.905 & 3 \\
\hline Interaction $\mathrm{P} \times \mathrm{S}$ & 104 & $1.744 *$ & 5 & 104 & $4.438^{*}$ & 14 \\
\hline Error & 312 & 1.360 & 12 & 312 & 3.364 & 33 \\
\hline
\end{tabular}

Note. The level of significance: $* \mathrm{p}<0.05, * * \mathrm{p}<0.01, * * * \mathrm{p}<0.001$.

Table 3 Geographic and climatic variables for European silver fir trial sites

\begin{tabular}{lcccccccccccc}
\hline Trials & $\begin{array}{c}\text { Prove- } \\
\text { nance } \\
\text { region }\end{array}$ & $\begin{array}{c}\text { Alti- } \\
\text { tude } \\
\mathrm{m}\end{array}$ & $\begin{array}{c}{ }^{0} \mathrm{CMA} \\
\mathrm{TM}^{0} \mathrm{C}\end{array}$ & $\begin{array}{c}\mathrm{TM}_{\mathrm{JAN}} \\
{ }^{0} \mathrm{C}\end{array}$ & $\begin{array}{c}\mathrm{TM}_{\mathrm{JUL}} \mathrm{C} \\
{ }^{0} \mathrm{CEG}\end{array}$ & $\begin{array}{c}\mathrm{PMA} \\
\mathrm{mm}\end{array}$ & $\begin{array}{c}\mathrm{PM}_{\mathrm{JAN}} \\
\mathrm{mm}\end{array}$ & $\begin{array}{c}\mathrm{PM}_{\text {JUL }} \\
\mathrm{mm}\end{array}$ & $\begin{array}{c}\mathrm{PM}_{\text {VEG }} \\
\mathrm{mm}\end{array}$ & $\begin{array}{c}\text { De Mar- } \\
\text { tonne } \\
\text { index }\end{array}$ \\
\hline $\begin{array}{l}\text { Băuțar } \\
\begin{array}{l}\text { Dom- } \\
\text { nești }\end{array}\end{array}$ & $\mathrm{D} 2$ & 650 & 6.20 & -3.57 & 15.78 & 12.18 & 904.40 & 58.24 & 103.84 & 558.28 & 55.83 \\
$\begin{array}{l}\text { Moi- } \\
\text { nești }\end{array}$ & $\mathrm{A} 2$ & 880 & 5.90 & -3.64 & 15.73 & 11.96 & 853.14 & 37.65 & 119.78 & 577.77 & 53.66 \\
$\begin{array}{l}\text { Săcele } \\
\text { Strâmbu }\end{array}$ & $\mathrm{B} 1$ & 1225 & 3.91 & -5.17 & 13.47 & 9.76 & 946.60 & 41.36 & 135.91 & 653.11 & 68.08 \\
Băiuț & $\mathrm{A} 1$ & 890 & 5.62 & -4.54 & 15.40 & 11.86 & 953.45 & 61.17 & 117.11 & 574.45 & 61.03 \\
\hline
\end{tabular}

Table 4 The best climatic transfer models developed for total height of European silver fir provenances at 31 years old

\begin{tabular}{|c|c|c|c|c|c|}
\hline Trial & Climatic transfer model & $D F$ & $R^{2}$ & $\begin{array}{l}\text { Partial } R^{2} \\
\text { Temperature }\end{array}$ & Precipitation \\
\hline Domnești & $17.384+0.004 D_{-} \mathrm{TMA}^{2}-0.012{\mathrm{D} \_P M_{\text {JUL }}}$ & 25 & 0.063 & 0.001 & 0.062 \\
\hline Moinești & $17.240-0.208 \mathrm{D} \_\mathrm{TMA}+0.001 \mathrm{D} \_\mathrm{PM}_{\mathrm{JUL}}^{2}$ & 25 & 0.097 & 0.084 & 0.068 \\
\hline Băuțar & $17.231-0.052 \mathrm{D} \_\mathrm{TMA}^{2}-0.0004 \mathrm{D}_{-} \mathrm{PM}_{\mathrm{JUL}}^{2}$ & 25 & 0.072 & 0.023 & 0.045 \\
\hline $\begin{array}{l}\text { Strâmbu } \\
\text { Băiuț }\end{array}$ & $13.175+0.015 \mathrm{D}_{-} \mathrm{TM}_{\mathrm{JUL}}^{2}-0.009 \mathrm{D} \_\mathrm{PM} \mathrm{JUL}_{\mathrm{JU}}$ & 25 & 0.060 & 0.013 & 0.046 \\
\hline Săcele & $12.508-0.014 \mathrm{D}_{-} \mathrm{TM}_{\mathrm{JUL}}^{2}-0.0001 \mathrm{D} \_\mathrm{PMA}^{2}$ & 25 & 0.153 & 0.064 & 0.011 \\
\hline
\end{tabular}

Note. Abbreviations: D_TMA is the differences in annual mean temperature between the location of a given provenance and of the trial site; D_TMJUL is the differences in mean temperature of the warmest month between the location of a given provenance and of the trial site; D_PMA is the differences in annual mean total precipitations between the location of a given provenance and of the trial site; D_PMJUL is the differences in mean precipitations of the warmest month between the location of a given provenance and of the trial site.

tion variables. The climatic variables involved in these models depend on test site, thus at wet sites were D_TMA and D_PM ${ }_{\mathrm{JUL}}$, and at very wet sites were D_TM ${ }_{\mathrm{JUL}}, \mathrm{D}_{-} \mathrm{PM}_{\mathrm{JUL}}$ or D_PMA. For H31, all individual transfer models were non-significant, while for D31 were significant only in two trial sites: Săcele and Moinești. Săcele trial is situated at the upper altitudinal limit of European silver fir distribution and at Moinești trial PMA is less than optimum and 
Table 5 The best climatic transfer models developed for diameter at $1.30 \mathrm{~m}$ of European silver fir provenances at 31 years old

\begin{tabular}{|c|c|c|c|c|c|}
\hline \multirow[b]{2}{*}{ Trial } & \multirow[b]{2}{*}{ Climatic transfer model } & \multirow[b]{2}{*}{$D F$} & \multirow[b]{2}{*}{$R^{2}$} & \multicolumn{2}{|c|}{ Partial $R^{2}$} \\
\hline & & & & $\begin{array}{l}\text { Tempe- } \\
\text { rature }\end{array}$ & $\begin{array}{l}\text { Preci- } \\
\text { pitation }\end{array}$ \\
\hline Domnești & $20.980-0.004 D_{-}{ }^{2} \mathrm{TMA}^{2}-0.019 \mathrm{D}_{-} \mathrm{PM}_{\text {JUL }}$ & 25 & 0.063 & 0.001 & 0.063 \\
\hline Moinești & $18.253-0.515 \mathrm{D}_{-} \mathrm{TMA}+0.002 \mathrm{D}_{-} \mathrm{PM}_{\mathrm{JUL}}^{2}$ & 25 & 0.252 & 0.191 & 0.220 \\
\hline Băuțar & $19.692-0.066 \mathrm{D}_{-}^{-} \mathrm{TMA}^{2}-0.016 \mathrm{D} \_\mathrm{PM}_{\mathrm{JUL}}$ & 25 & 0.120 & 0.053 & 0.072 \\
\hline $\begin{array}{l}\text { Strâmbu } \\
\text { Băiuț }\end{array}$ & $17.215+0.030 \mathrm{D}_{-} \mathrm{TM}_{\mathrm{JUL}}^{2}-0.001 \mathrm{D} \mathrm{PM}_{\mathrm{JUL}}^{2}$ & 25 & 0.108 & 0.027 & 0.104 \\
\hline Săcele & $16.836-0.041 \mathrm{D} \_\mathrm{TM}^{2}{ }_{\mu \Psi}-0.0001 \mathrm{D} \_\mathrm{PMA}^{2}$ & 25 & 0.251 & 0.188 & 0.102 \\
\hline
\end{tabular}

Note. Abbreviations similar to table 4.

the De Martonne aridity index is the lowest. Both sites are situated inside of species distribution, in the mixed forests layer, but in suboptimal climates for species. The values of partial $R^{2}$ (Table 5) showed that D_PM JUL $_{\text {at Moinești }}$ trial and D_TM $\mathrm{JUL}_{\mathrm{J}}$ at Săcele trial are the most important climate variables to climatic transfer. Figure 2 illustrates the transfer functions for D31 at Săcele trial. Although in most studies, data from multiple test sites were pooled to generate a generalized transfer function, we could not develop a transfer function at species distribution scale since the provenance $\mathrm{x}$ site interaction was significant.

\section{Growth response functions}

Table 6 summarises the response functions of European silver fir provenances for H31 and D31 over the testing sites. In terms of $R^{2}$, the relationships with TMA and PMA of trial site for both traits were very significant. In the case of $\mathrm{H} 31$, the climate variables had almost similar influence, explaining $56 \%$ and $60 \%$ of the total variation (partial $R^{2}$ ), respectively. However, regarding D31, the trial site TMA was the most important predictor, accounted for 33\% of the variation.

The transfer of populations to warmer environments (Domnești and Băuțar trials, mountain beech layer) resulted in an increase of the growth - mainly due to a longer growing season. However, the developed growth response models are quadratic functions. TMA and
PMA of the planting site constitute the limitative factors and at some point maladaptation will occur. The growth response functions across all sites are presented in Figures 3-4.

The magnitude of variation is directly proportional to plastic capacity of provenances. Ecovalence analyses were performed for that purpose, allowing the identification of provenances with high adaptive capacity and stability to environmental variations. According with Becker \& Leon (1988), the genotypes with zero ecovalence value are regard as stable across environments. Based on the ecovalence values and their variances, European silver fir provenances could be separated into four groups: high stability and high growth, high stability and low growth, low stability and high growth, and low stability and low growth. The provenances which have highlighted good growth performances (over the experiment mean for both traits) and high stability (ecovalence near zero) were: 2-Azuga, 4-Avrig, 14-Asău, 47-Moinești, 50-Mălini, 13-Soveja, 53-Botiza, 5-Valea Moților, 9-Polovragi (Fig. 5). The weakest and unstable growth performances had the following provenances: 52-Solca, 17-Gârcina, 11-Gura Teghii, while provenance 20-Rusca Montană (Banat Mountains) has obtained the weakest growth in all planting sites. We did not found any correlations between ecovalence values and the climate variables of the provenances location. 
Table 6 Climatic response models developed for total height and diameter at $1.30 \mathrm{~m}$ of European silver fir provenances at 31 years old

\begin{tabular}{llllll}
\hline Trait & \multirow{2}{*}{ Climatic response model } & $p$ & \multirow{2}{*}{$R^{2}$} & Partial $R^{2}$ & \\
\cline { 5 - 6 } & & & & Temperature & Precipitation \\
\hline H31 & $14.407+1.591 \mathrm{TMA}-0.0001 \mathrm{PMA}^{2}$ & $<0.001$ & 0.791 & 0.560 & 0.608 \\
D31 & $15.164+1.290 \mathrm{TMA}-0.0001 \mathrm{PMA}^{2}$ & $<0.001$ & 0.478 & 0.329 & 0.171 \\
\hline
\end{tabular}

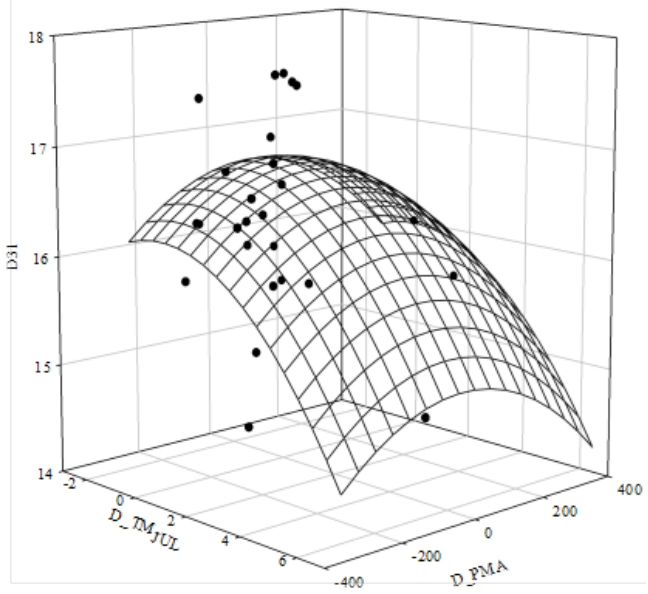

\section{Figure 2}

The transfer function for diameter at $1.30 \mathrm{~m}$ of European silver fir provenances at Săcele trial. D_TMJUL represent the difference in mean temperature of the warmest month between the location of a given provenance and of the trial site; D_PMA is the differences in annual mean total precipitations between the location of a given provenance and of the trial site.
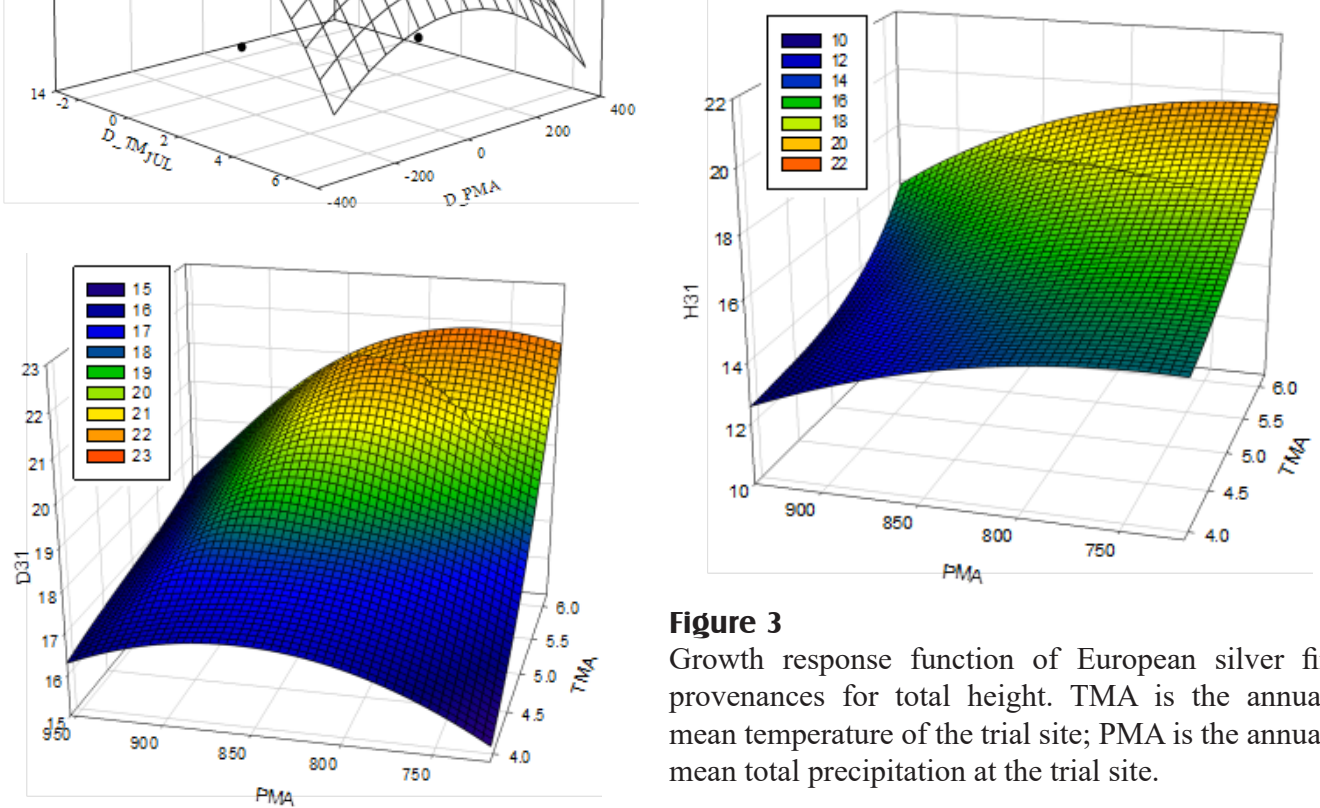

Figure 3

Growth response function of European silver fir provenances for total height. TMA is the annual mean temperature of the trial site; PMA is the annual mean total precipitation at the trial site.

Figure 4 Growth response function of European silver fir provenances for diameter at $1.30 \mathrm{~m}$. TMA is the annual mean temperature of the trial site; PMA is the annual mean total precipitation at the trial site.

\section{Potential impact of climate change projec- tions}

The populations' response models (Table 6) were used to predict the potential impacts of climate change on current distribution of Eu- ropean silver fir in Romania. Prediction models were tested using the RCP4.5 scenario and results are summarised in Table 7 . Thus, warming will cause some changing in current distribution of European silver fir in Romania. The gained area, until the year 2100 will be 


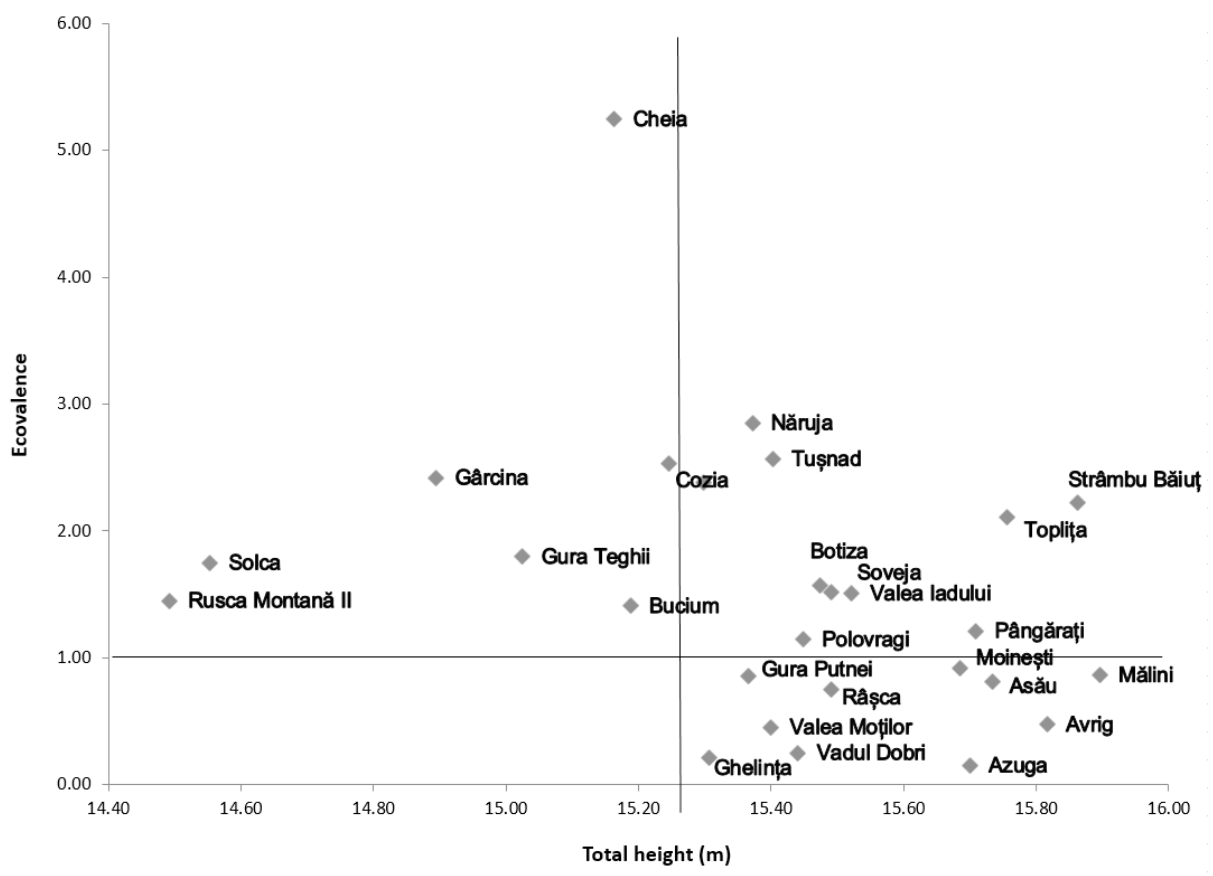

Figure 5 Ecovalence for total height of European silver fir populations at 31 years old

Table 7 Changes in present natural distribution of European silver fir as predicted by the response functions under the RCP4.5 scenario

\begin{tabular}{lllll}
\hline \multirow{2}{*}{ Period } & RCP 4.5 scenario & \multicolumn{3}{l}{ Percentage change in present natural distribution } \\
\cline { 3 - 5 } & TMA $\left({ }^{\circ} \mathrm{C}\right)$ & Gain area & Lose area & Total remaining area \\
\hline $2021-2050$ & $+1.4(0.9-2.0)$ & +4.0 & -4.1 & 99.9 \\
$2051-2100$ & $+1.8(1.1-2.6)$ & +4.1 & -6.9 & 97.1 \\
\hline
\end{tabular}

$8.1 \%$, while the lose area will be $11 \%$. Figure 6 shows the changes in species present distribution and which will be the areas where the populations will be maladapted over the next decades.

\section{Discussion}

European silver fir is an exigent species in terms of climatic-edaphic conditions (Şofletea \& Curtu 2001). In Romania, its optimum climate is in the mixed mountain forests, characterised by annual mean temperature between $4.0^{\circ} \mathrm{C}$ to $6.5^{\circ} \mathrm{C}$ and precipitations between 800 to1100 mm (Enescu \& Doniță 1988, Doniță et al. 1990).

Long-term climatic changes over Romania are well documented in various recent papers (Birsan et al. 2014, Cheval et al. 2014a, 2014b, Marin et al. 2014), pointing to a significant warming in all seasons except autumn (Dumitrescu et al. 2015, Dobrinescu et al. 2015), an increase in frequency of rain showers $(\mathrm{Bu}-$ suioc et al. 2015, 2016; Manea et al. 2016), decreasing wind speed (Birsan et al. 2013) and snow pack (Birsan \& Dumitrescu 2014). In last decades, climatic changes have varied 


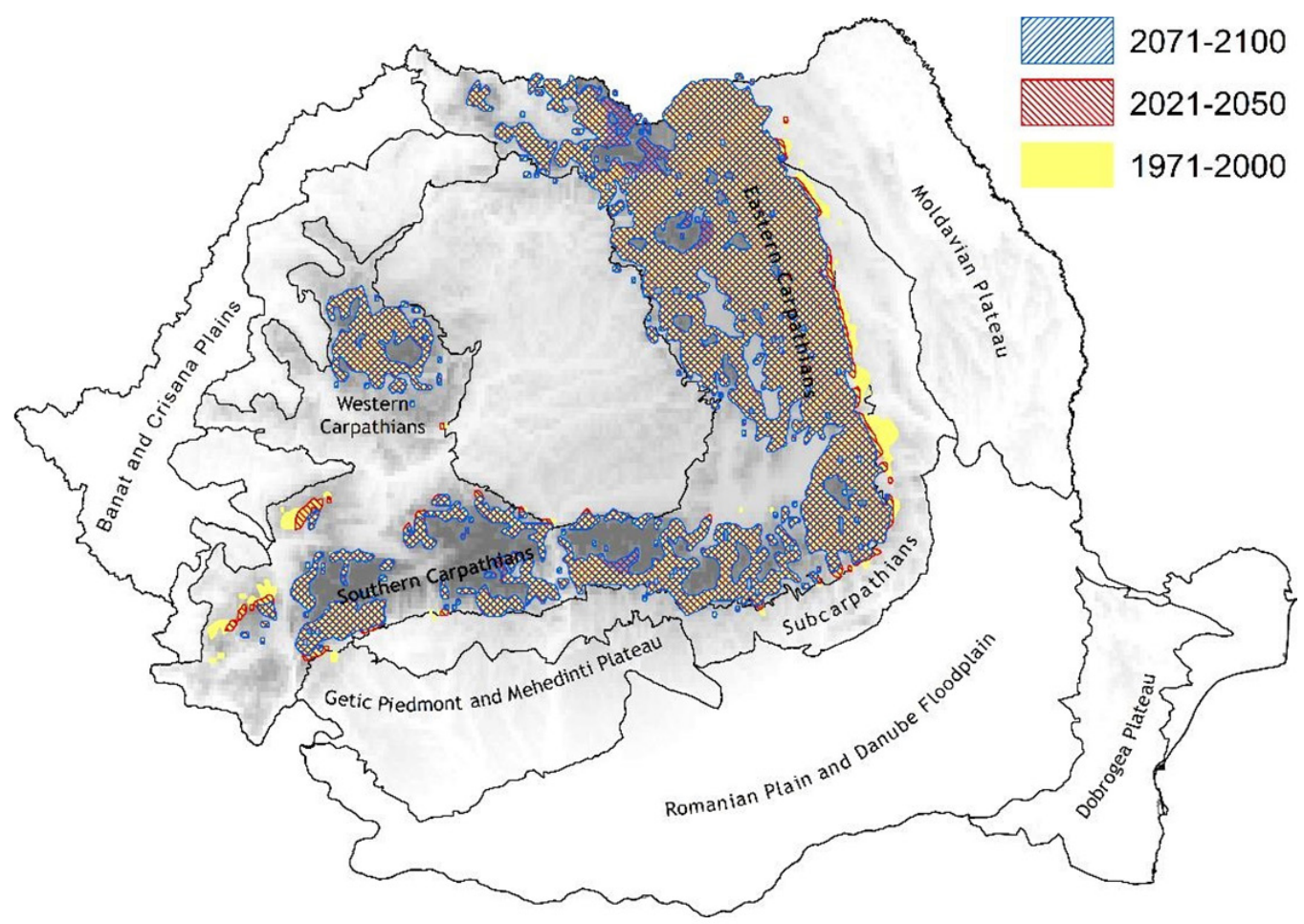

Figure 6 Changes in natural distribution of European silver fir until 2100. In yellow: the present distribution, in striped red: 2021-2050, in striped blue: 2071-2100.

among geographic regions of Romania (Birsan 2015). Thus, the magnitude of climate changes which occurred among European silver fir provenance trials varied during the evaluation period. This regional - specific climate change has determined an increase of the growth in Băuțar and Domnești trials situated in warmer and moister regions where both annual mean temperature and precipitations increased or precipitations decreased insignificantly (Table 3 ). The site factor had a greater influence on species growth performances than genetic factor, at this age. Results show that the growth was very significantly influenced by the annual mean temperature (TMA) and total mean precipitations (PMA) of the trial sites. These are the driving factors of tree growth that should be associated with the risk in case of the transfer of forest reproductive materials.
Also, there is a large genetic variability among studied provenances in terms of growth traits that suggests a local adaptation to the climate of the origin location of provenances. The developed transfer models have allowed highlighting the climate variables, which have the most important role to the transfer of European silver fir reproductive materials. The climatic variables involved in these models were the differences in TMA, TM ${ }_{\mathrm{JUL}}, \mathrm{PM}_{\mathrm{JUL}}$ and PMA between the origin location of a given provenance and the trial site. These are the major climatic factors controlling genetic differentiation of European silver fir provenances and limiting how far the forest reproductive material could be transferred among provenances regions. The transfer models were generally low, significant models were obtained for D31 and in two sites only $\left(R^{2}=0.251\right)$. Results 
could be explained by the very high influence of the environmental factor, which accounted $78 \%$ (for $\mathrm{H} 31$ ) to $45 \%$ (for D31) from total variance, at this age. However, the population transfer functions seem to be significant at those sites situated in climatically marginal environments (higher elevation and the lowest PMA). These results suggest that the provenance origin should be especially considered if the species will be planted outside of its current climate optimum. Lack of significance for the transfer functions in the other sites can be explain by the fact they were in climatic optimum of the species. The results are in accordance with those reported for other species (Carter 1996, Andalo et al. 2005, Rweyongeza et al. 2007). Individual or general transfer functions are generally low and could explain at most $30-55 \%$ of total height variation (Wang et al. 2010).

In all planting sites, the best provenances, which have produced the greatest yield, are non-local sources. Generally, in almost all transfer models, the values of the predictors were negative and suggest that the best provenances in terms of total height and diameter at $1.30 \mathrm{~m}$ came from origin climate close to site climate (small transfer distances). Except Sacele trial, D_PM ${ }_{\text {JUL }}$ is the major factor of variation for D31 (partial $R^{2}$, Table 5), while for H31 both D_PM ${ }_{\text {JUL }}$ and D_TMA are important factors.

The growth response functions developed are quadratic regression models indicating that growth will decline exponentially as the seed sources will depart from a climatic optima. TMA and PMA of site together explain 79\% and $48 \%$ of the total phenotypic variation observed in $\mathrm{H} 31$ and D31, respectively. Also, the provenance $\mathrm{x}$ site interaction was very significant and shows that growth performances are limited by environment conditions of planting site and they could change from site to site. However, the ecovalence values emphasize that there are provenances exhibiting high phenotypic plasticity. Based on the ecovalenc- es calculated for $\mathrm{H} 31,58 \%$ of the provenances belong to the category „high stability and high growth". Results are suported by the recent studies which show that European silver fir is more resilient to climate change than other conifers of temperate forests (Becker 1989, Zang et al. 2014, Gazol \& Camarero 2016).

Future projections suggest that the trend toward warmer climatic conditions will continue in the coming decades. Based on growth response functions and RCP4.5 scenario we could project the shifts in species distribution for $2050 \mathrm{~s}$ and $2100 \mathrm{~s}$. Thus, the gained area until the year 2100 will be $8.1 \%$ through migration to high elevations, while the lost area will be $11 \%$. Our results confirm that climate changes could increase the European silver fir productivity at higher elevations as a consequence of improving growth conditions. The most vulnerable populations will be those from climatically marginal environments, from low elevations and facing higher temperatures coupled with moisture deficiency, like the edges of the Eastern Carpathians and the Banat Mountains; Figure 6 presents how the European silver fir range will withdraw in the eastern and south-western part of their distribution.

\section{Conclusions}

The experiments revealed a large genetic variability within species level. European silver fir populations demonstrated resilience to climate change, which certainly is adaptive and has a genetic basis. However, changes in environmental conditions can affect the phenotype of particular provenances and thus the transfer of forest reproductive material must be done with caution.

The transfer to warmer climate, at lower altitude, in mountain beech layer, resulted in an increase of the provenances growth. But growth is significantly influenced by TMA and PMA of planting site and also by the differences in TMA, TM ${ }_{\mathrm{JUL}}, \mathrm{PM}_{\mathrm{JUL}}$ and PMA between 
provenance site and test site. These are the climatic factors which should be associated with risk in case of a transfer of provenances.

The transfer of European silver fir populations to small climatic distances will contribute to enhance growth and could be a key forest management strategy to mitigate negative impacts of climate change in some areas.

The study highlights the importance of the long-term genetic tests and assisted migration in evaluating the adaptive capacity of forest species to climate changes. The risk of maladapted reproductive material can be minimized if we consider genetic differences within species and will identify the best performing and adapted provenances for each provenance region.

\section{Acknowledgements}

We acknowledge the World Climate Research Programme's Working Group on Regional Climate, and the Working Group on Coupled Modelling, former coordinating body of CORDEX and responsible panel for CMIP5. We also thank the climate modelling groups CLMcom Consortium and Max-Planck Institute (Climate Service Center, Hamburg) for producing and making available their model output. We also acknowledge the Earth System Grid Federation infrastructure an international effort led by the U.S. Department of Energy's Program for Climate Model Diagnosis and Intercomparison, the European Network for Earth System Modelling and other partners in the Global Organisation for Earth System Science Portals (GO-ESSP). The authors also thank the anonymous reviewer for the useful comments on earlier versions of this manuscript.

This work was realised within the framework of GENCLIM project ("Evaluating the adaptive genetic potential of the main coniferous species for a sustainable forest management in the context of climate change") - PN-II-PC-PCCA-2013-4-0695, financed by 106
Executive Agency for Higher Education, Research, Development and Innovation Funding.

\section{References}

Aitken S.N., Yeaman S., Holliday J.A., Wang T., Curtis-McLane S., 2008. Adaptation, migration or extirpation: climate change outcomes for tree populations. Evolutionary Applications 1: 95-111. DOI: 10.1111/j.1752-4571.2007.00013.x

Aldalo C., Beaulieu J., Bousquet J., 2005. The impact of climate change on growth of local white spruce populations in Quebec. Can.For.Ecol.Manage 205: 169-182. DOI: $10.1016 /$ j.foreco.2004.10.045

Becker H.C., Leon J., 1988. Stability analysis in plant breeding. Plant Breeding 101: 1-23. DOI: 10.1111/ j.1439-0523.1988.tb00261.x

Becker M., 1989. The role of climate on present and past vitality of silver fir forest in the Vosges mountains of Northeastern France. Canadian Journal of Forest Research 19: 1110-1117. DOI: 10.1139/x89-168

Birsan M.V., 2015. Trends in monthly natural streamflow in Romania and linkages to atmospheric circulation in the North Atlantic. Water Resources Management 29(9): 3305-3313. DOI: 10.1007/s11269-015-0999-6

Birsan M.V., Dumitrescu A., 2014. Snow variability in Romania in connection to large-scale atmospheric circulation. International Journal of Climatology 34: 134-144. DOI: $10.1002 /$ joc. 3671

Birsan M.V., Dumitrescu A., Micu D.M., Cheval S., 2014. Changes in annual temperature extremes in the Carpathians since AD 1961. Natural Hazards 74(3): 18991910. DOI: $10.1007 / \mathrm{s} 11069-014-1290-5$

Birsan M.V., Marin L., Dumitrescu A., 2013. Seasonal changes in wind speed in Romania. Romanian Reports in Physics 65(4): 1479-1484.

Busuioc A., Birsan M.V., Carbunaru D., Baciu M., Orzan A., 2016. Changes in the large-scale thermodynamic instability and connection with rain shower frequency over Romania. Verification of the Clausius-Clapeyron scaling. International Journal of Climatology 36(4): 2015-2034. DOI: 10.1002/joc.4477

Busuioc A., Dobrinescu A., Birsan M.V., Dumitrescu A., Orzan A., 2015. Spatial and temporal variability of climate extremes in Romania and associated large-scale mechanisms. International Journal of Climatology 35(7): 1278-1300. DOI: 10.1002/joc.4054

Carter K.K., 1996. Provenance tests as indicators of growth response to climate change in 10 north temperate tree species. Canadian Journal of Forest Research 26: 1089-1095. DOI: 10.1139/x26-120

Cheval S., Busuioc A., Dumitrescu A., Birsan M.V., 2014a. Spatiotemporal variability of meteorological drought in Romania using the standardized precipitation index (SPI). Climate Research 60: 235-248. DOI: $10.3354 / \mathrm{cr} 01245$ 
Cheval S., Birsan M.V., Dumitrescu A., 2014b. Climate variability in the Carpathian Mountains Region over 1961-2010. Global and Planetary Change 118: 85-96. DOI: 10.1016/j.gloplacha.2014.04.005

Cheval S., Dumitrescu A., Birsan M.V., 2017. Variability of the aridity in the South-Eastern Europe over 1961-2050. Catena 151: 74-86. DOI: 10.1016/j.catena.2016.11.029

Dobrinescu A., Busuioc A., Birsan M.V., Dumitrescu A., 2015. Changes in thermal discomfort indices in Romania and responsible large-scale mechanisms. Climate Research 64(3): 213-226. DOI: 10.3354/cr01312

Doniță N., Chiriță C.D., Stănescu V., 1990. Tipuri de ecosisteme forestiere [Forest ecosystems types]. Editura Tehnică Silvică, Bucharest, 496 p.

Dumitrescu A., Birsan M.V., 2015. ROCADA: a gridded daily climatic dataset over Romania (1961-2013) for nine meteorological variables. Natural Hazards 78(2): 1045-1063. DOI: 10.1007/s11069-015-1757-z

Dumitrescu A., Bojariu R., Birsan M.V., Marin L., Manea A., 2015. Recent climatic changes in Romania from observational data (1961-2013). Theoretical and Applied Climatology 122(1-2): 111-119. DOI: 10.1007/s00704014-1290-0

Dumitrescu A., Birsan M.V., Manea A., 2016. Spatio-temporal interpolation of sub-daily (6- hour) precipitation over Romania for the period 1975-2010. International Journal of Climatology 36(3): 1331-1343. DOI: 10.1002/joc. 4427

Dumitrescu A., Birsan M.V., Nita I.A., 2017. A Romanian daily high-resolution gridded dataset of snow depth (2005-2015). Geofizika 34(2): 275-295. DOI: 10.15233/gfz.2017.34.14

Enescu V., Doniță N., 1988. Zonele de recoltare a semințelor forestiere în R.S. România [Provenance regions for harvesting the seeds in R.S. Romania]. Redacția de Propagandă Tehnică Agricolă, Seria II, Bucharest, $60 \mathrm{p}$.

EFI, 2008. Impacts of Climate Change on European Forests and Options for Adaption. Report of the European Forest Institute to the European Commission Directorate-General for Agriculture and Rural Development. Joensuu.

Farjat A. E., Isik F., Reich B. J., Whetten R. W., McKeand S. E., 2015. Modeling climate change effects on the height growth of Loblolly Pine. Forest Science 61 (4): 703-715. DOI: 10.5849/forsci.14-075

Ficko A., Poljanec A., Boncina A., 2011. Do changes in spatial distribution, structure and abundance of silver fir (Abies alba Mill.) indicate its decline? Forest Ecology and Management 261: 844-854. DOI: 10.1016/j.foreco.2010.12.014

Gazol A., Camarero J.J., 2016. Functional diversity enhances Silver fir growth resilience to an extreme drought. Journal of Ecology 104(4): 1063-1075. DOI: 10.1111/1365-2745.12575

Jump A.S., Hunt J.M., Penuelas J., 2006. Rapid climate change-related growth decline at the southern edge of Fagus sylvatica. Global Change Biology 12: 21632174. DOI: $10.1111 /$ j.1365-2486.2006.01250.x

Kapeller S., Lexer M.J., Geburek T., Hiebl J., Schueler S., 2012. Intraspecific variation in climate response of Norway spruce in the Eastern Alpine range: Selecting appropriate provenances for future climate. Forest Ecology and Management 271: 46-57. DOI: 10.1016/j. foreco.2012.01.039

Kremer A., 2007. How well can existing forests withstand climate change. Climate change and forest genetic diversity. Implications for sustainable forest management in Europe. In: Koskela J., Buck A., Teissier du Cros E. (eds.), Bioversity International, Rome, pp. 3-17.

Lindner M., 2000. Developing adaptive forest management strategies to cope with climate change. Tree Physiology 20: 299-307. DOI: 10.1093/treephys/20.5-6.299

Manea A., Birsan M.V., Tudorache G., Cărbunaru F., 2016. Changes in the type of precipitation and associated cloud types in Eastern Romania (1961-2008). Atmospheric Research 169: 357-365. DOI: 10.1016/j. atmosres.2015.10.020

Marcu M., 1983. Meteorologie și climatologie forestieră [Forest meteorology and climatology]. Editura Ceres, Bucharest, $250 \mathrm{p}$.

Marin L., Birsan M.V., Bojariu R., Dumitrescu A., Micu D.M., Manea A., 2014. An overview of annual climatic changes in Romania: trends in air temperature, precipitation, sunshine hours, cloud cover, relative humidity and wind speed during the 1961-2013 period. Carpathian Journal of Earth and Environmental Sciences 9(4): 253-258.

Matyas C., 1994. Modelling climate change effects with provenance test data. Tree Physiology 14: 797-804. DOI: $10.1093 /$ treephys/14.7-8-9.797

Mihai G., Mirancea I., Duță C., 2014. Variation of the quantitative traits in a progeny test of Abies alba (Mill.) at the nursery stage. Silvae Genetica 63(6):275-284. DOI: $10.1515 / \mathrm{sg}-2014-0035$

Mihai G., Mirancea I., 2016. Age trends in genetic parameters for growth and quality traits in Abies alba. iForest 9: 954-959. DOI: 10.3832/ifor 1766-009

NSI, 2015. National Statistic Inventory, Web: www.insse. ro. Accessed: 12.2017.

Pârnuță Gh., Budeanu M., Stuparu E., 2012. Catalogul național al materialelor forestiere de reproducere [National Catalog of basic materials for producing the forest reproductive materials]. Editura Silvică, Bucharest, $334 \mathrm{p}$.

Price T.D., Qvarnström A., Irwin D.E., 2003. The role of phenotypic plasticity in driving genetic evolution. Proceedings of the Royal Society London 270: 1433-1440. DOI: $10.1098 / \mathrm{rspb} .2003 .2372$

Rehfeldt G.E., 1994a. Adaptation of Picea englemannii populations to the heterogeneous environments of the Intermountain West. Canadian Journal of Botany 72: 1197-1208. DOI: 10.1139/b94-146

Rehfeldt G.E., Tchebakova N.M., Barnhardt L.K., 1999a. Efficacy of climate transfer functions: introduction of 
Eurasian populations of Larix into Alberta. Canadian Journal of Forest Research 29: 1660-1668. DOI: 10.1139/x99-143

Rehfeldt G.E., Ying C.C., Spittlehouse D.L., Hamilton D.A., 1999b. Genetic responses to climate in Pinus contorda: niche breadth, climate change, and reforestation. Ecological Monographs 69: 375-407. DOI: 10.1890/0012-9615(1999)069[0375:GRTCIP]2.0.CO;2

Rweyongeza D.M., Yang R.C., Dhir N.K., Barnhardt L.K., Hansen C., 2007. Genetic variation and climatic impacts on survival and growth of white spruce in Alberta, Canada. Silvae Genetica 56: 3-4. DOI: 10.1515/ sg-2007-0018

Salinger M.J., 2005. Climate variability and change: past, present and future-an overview. Climatic Change 70 : 9-29. DOI: 10.1007/s10584-005-5936-X

Savolainen O., Bokma F., Garcia-Gil M.R., Komulainen P., Repo T., 2004. Genetic variation in cessation of growth and frost hardiness and consequences for adaptations of Pinus sylvestris to climatic changes. Forest Ecology and Management 197: 79-89. DOI: 10.1016/j. foreco.2004.05.006

Schmidtling R. C., 1994. Use of provenance tests to predict response to climate change: Loblolly Pine and Norway spruce. Tree Physiology 14 (7-8-9): 805-17.
Șofletea N., Curtu L., 2001. Dendrologie [Dendrology]. Editura Pentru Viață, Brașov, 296 p.

Thomson A.M.,Calvin K.V., Smith S.J., Kyle G.P., Volke A., Patel P., Delgado-Arias S., Bond-Lamberty B., Wise M.A., Clarke L.E., Edmonds J.A., 2011. RCP4.5: a pathway for stabilization of radiative forcing by 2100 . Climatic Change 109: 77-94. DOI: 10.1007/s10584011-0151-4

Wang T., O’Neill G.A., Aitken S.N., 2010. Integrating environmental and genetic effects to predict responses of tree populations to climate. Ecological Applications 20 (1): 153-163. DOI: 10.1890/08-2257.1

Weisgerber H., Sindelar J., 1992. IUFRO's role in coniferous tree improvement. History, results and future trends of research and international cooperation with European larch. Silvae Genetica 41 (3): 150-160.

Wrike S.G., 1962. Ube eine mthodezur Erfussung der Okologischen streubreite in Feldversuchen [A method for the observation of the ecological range in field trials]. Z. Pflanzenzuechi 47: 92-96.

Zang C., Hartl-Meier C., Dittmar C., Rothe A., Menzel A., 2014. Patterns of drought tolerance in major European temperate forest trees: climatic drivers and levels of variability. Global Change Biology 20: 3767-3779. DOI: $10.1111 / \mathrm{gcb} .12637$ 